\title{
The sectoral drivers of economic growth: A long-term view of Latin American economic performance ${ }^{1}$
}

\author{
Alejandra Acevedo \\ Economic Commission for Latin America and the Caribbean \\ (ECLAC, Chile) \\ Andrew Mold \\ The Development Centre \\ Organisation for Economic Co-Operation and Development \\ (OECD, France) \\ Esteban Perez \\ Economic Commission for Latin America and the Caribbean \\ (ECLAC, Chile)
}

\begin{abstract}
This paper explores the long-term relationship between economic growth and the allocation of resources among sectors for a panel of 18 Latin American countries over the period 1950- 2006. Using as high a level of disaggregation as the data allows, we use dynamic panel data analysis to calculate the elasticities of sectoral growth to overall output. This captures the strength of the linkages between sectors and gives some indication of which sectors can be considered to be 'drivers of growth'. While it is traditionally believed that the manufacturing sector is the 'engine of growth', empirical results show that with the rise of the so-called 'new economy', a more nuanced reply is required, and that other sectors can also serve as catalysts for faster growth. In particular, we find support for the proposition that certain groups of services can also play the role of 'leading sectors'. Pointedly, however, the results show a consistently low or negligible relationship between primary resource sectors and economic growth. These results are put in perspective of the debates on 'deindustrialisation' and 'premature de-industrialisation'. The causes and the implications of this process for policies to enhance long-term growth and technological acquisition are discussed.
\end{abstract}

Keywords: Economic development, allocation of resources, drivers of growth, service sector.

Classification JEL: O11, O54, O57.

\section{Resumen}

Este trabajo investiga la relación a largo plazo entre el crecimiento económico y la asignación de recursos entre los sectores productivos para 18 países de América Latina durante el período

${ }^{1}$ The opinions here expressed are the authors' own and may not coincide with those of ECLAC and/or OECD. The authors would like to thank Kiichiro Fukasuku, Helmut Reisen and Annalisa Prizzon for helpful comments on an earlier draft. Any errors of course remain the responsibility of the authors. 
1950-2006. Aprovechando el mayor nivel de desagregación permitido por los datos, se utiliza el análisis de datos de panel para determinar las elasticidades de los crecimientos sectoriales respecto al producto total de la economía. Esto permite recoger los estrechos vínculos entre sectores arrojando algún indicio sobre cuáles de éstos pueden ser considerados como "motores de crecimiento". Mientras que según el pensamiento tradicional el sector manufacturero es el "motor de crecimiento" por excelencia, los resultados empíricos demuestran que con la aparición de la llamada "nueva economía" se requiere una respuesta más matizada, ya que otros sectores también pueden actuar como catalizadores para lograr un crecimiento más rápido. Este trabajo da sustento a esta hipótesis mostrando que subgrupos del sector de servicios juegan el rol de "sectores líderes". Se destaca además, que los resultados reflejan una relación consistentemente débil o insignificante entre sectores primarios y crecimiento económico. Estos resultados se visualizan e interpretan desde la perspectiva de los debates sobre "desindustrialización" y "desindustrialización temprana". Por último, se discuten las causas e implicaciones de este proceso para políticas que estimulen el crecimiento a largo plazo y la adquisición de nuevas tecnologías.

Palabras Clave: Crecimiento, desindustrialización, leyes de Kaldor, motores de crecimiento, productividad, sector manufacturero, sector servicios.

Clasificación JEL: O11, O54, O57.

\section{Introduction}

Traditionally, one of the enduring issues concerning economists from the Latin American region has been the low level of industrial development and an overdependence on the export of primary commodities (see, inter alia, Prebisch 1950, Ocampo and Parra, 2003). This concern is based on a belief that a developed economy is an industrialized economy (Kregel, 2007). In the last two decades, however, the issue of industrialisation has taken a backseat in discussions of development strategy, as economic policymakers have focused on problems related to liberalization and macroeconomic stabilization. Purposely promoting industrial development has been much frowned upon during the last two decades. Krueger (2007) has been one of the most outspoken critics of such policies:

"Focusing on industrialization as a policy objective is almost certainly wrong. Mechanization and increasing productivity in all sectors usually leads to more rapid growth in industry than of other sectors, but that is the outcome of appropriate policy. While it highly likely that growth of agricultural productivity - a necessary part of overall economic growth - will shift returns to induce movement of workers to industrial (and service) activities, a focus on industrialization as an instrument, rather than an outcome, can lead to low growth if not stagnation".

In contrast, other authors (e.g. Hausmann and Rodrik, 2006: 697) argue that a 'laissez faire' attitude is hardly likely to achieve the desired consequences in terms of structural diversification and technological dynamism of the economy:

"Laissez-faire leads to under-provision of innovation and governments need to play a dual role in fostering industrial growth and transformation. They need to encourage 
entrepreneurship and investment in new activities ex ante, but push out unproductive firms and sectors ex post. This is of course easier said than done. The specifics of how this can be managed is likely to differ considerably from country to country, depending on administrative capability, the prevailing incentive regime, the flexibility of the fiscal system, the degree of sophistication of the financial sector, and the underlying political economy."

By means of some straightforward econometric tests of Kaldor's first Growth Law (which relates the strength of manufacturing sector growth for the overall performance of the economy), this paper revindicates the importance of the manufacturing sector for structural diversification and economic development in the region. But we also find a more nuanced conclusion in support of the manufacturing sector than in previous studies (e.g. Wells and Thirlwall (2003), who test the applicability of Kaldor's growth laws for African countries). In contrast to these and earlier studies, we investigate in some depth other potential 'engines of growth' exist outside the manufacturing sector. While broadly supporting the conclusions of earlier papers, we argue that, with the rise of the so-called 'new economy', a more nuanced reply is required, and that other sectors can also serve as catalysts for faster growth. In particular, we find support for the proposition that certain groups of services can also play the role of 'leading sectors'. Following Palma (2005), these results are put in perspective of the debates on 'de-industrialisation', and it is argued that Latin America has suffered from policy-induced de-industrialisation rather than from a natural shift towards services and other sectors.

The outline of the paper is as follows. Section 2 looks at existing theoretical and empirical literature concerning structural change and economic growth, focusing particularly on evidence regarding the Latin American experience. Section 3 contains the empirical analysis on a panel of 18 Latin American countries over the period 1950-2006, using three approaches: standard panel data analysis, a GMM estimation and a state space model. In Section 4, the causes and implications of this process for long-term growth and technological acquisition are discussed.

\section{Theoretical and Empirical Views on Structural Change in Latin America}

Early development economists addressed the problem of industrialization through different strategies aimed to catalyse broader development. These ranged from the big push ideas put forward by Rosenstein-Rodan (1957) and the balanced-unbalanced growth controversy that followed, to the dual sector Lewis model (1954) and Kaldor's growth laws (1966). Whatever their differences, these views shared some fundamental insights into the development process.

The relationship between development and industrialization were not, and indeed according to these theorists could not be, conceived in static terms as in Ricardian theory. This meant dispensing with the concept of full employment which is at the 
heart of optimal resource allocation theory. This approach also led to the introduction, early on, of the notion of increasing returns to scale. Increasing returns to scale are at the core of Rosenstein-Rodan big push as well as Lewis and Kaldor's views. The notion of increasing returns to scale provided the foundations for the study of structural change.

The dynamics of economic development necessarily involved the analysis of the interaction between economic sectors. Historically, at the time when these early development views were put forward the interaction analysis was mainly carried out in terms of dual sector analysis involving agriculture and industry (manufacturing). The relations between sectors were conceived in fairly simple terms. In the most known approach industry (manufacturing) would absorb the surplus labour emanating from agriculture allowing the sector to increase its productivity and standard of living. The improvement in agricultural conditions would allow the sector to generate a demand for manufacturing products, thereby creating the conditions for sustained growth and development.

The analysis even when framed in its most modern guise (Murphy, Shleifer, and Vishny, 1989) had some fundamental implications for economic development. Industrialization resulted from the coordination of investment plans and decisions across sectors; complementarities between sectors worked through market size effects; the whole process of development and industrialization required a certain degree of government intervention.

In the late 1980s, in the aftermath of the debt crisis Latin American countries underwent a dramatic shift in their economic policies, away from the previous policies of import-substitution and towards a more liberal model, based on the Washington Consensus (Williamson, 2003; Bulmer Thomas, 2003). Despite achieving fast rates of economic growth during the 1960s and 70s, and quite notable structural change towards manufactures (though not of exports), conventional wisdom deemed these policies unsustainable and, under the tutelage of organizations like the World Bank and the IMF, practically the whole continent shifted towards more liberal policies.

The switch of policies did not deliver the kind of economic performance that their proponents anticipated. The 1980's debt crisis marked a break point in the long-term growth trajectory of Latin American economies (Figure 1). Growth rates turned out to be much lower during the period of market liberalization. While it is true that between 2003-7 economic growth in per capita has recovered, and has in fact been the strongest seen the decade of the 1960s (ECLAC, 2007), nevertheless, it is arguable whether this corresponds to a belated payoff from the New Economic Model, or is better attributed to a rise in commodity prices. In this context, a number of authors have raised legitimate doubts about whether this improved performance is sustainable over the long-term (Izquierdo, Romero and Talvi, 2008). It would seem that improved economic performance at the regional level has thus become very much tied to expectations of commodity prices attaining a permanently higher level in the future (i.e. the debate over whether we have moved into a commodities 'supercycle', driven 
by, among other things, the rising demand for commodities from the Asian drivers (China and India) (see, for instance, Cuddington and Jerrett, 2008).

FIGURE 1

LATIN AMERICA 1961-2006. ACTUAL RATE OF GROWTH AND ITS TREND COMPONENT (HODRICK-PRESCOTT FILTER METHOD)

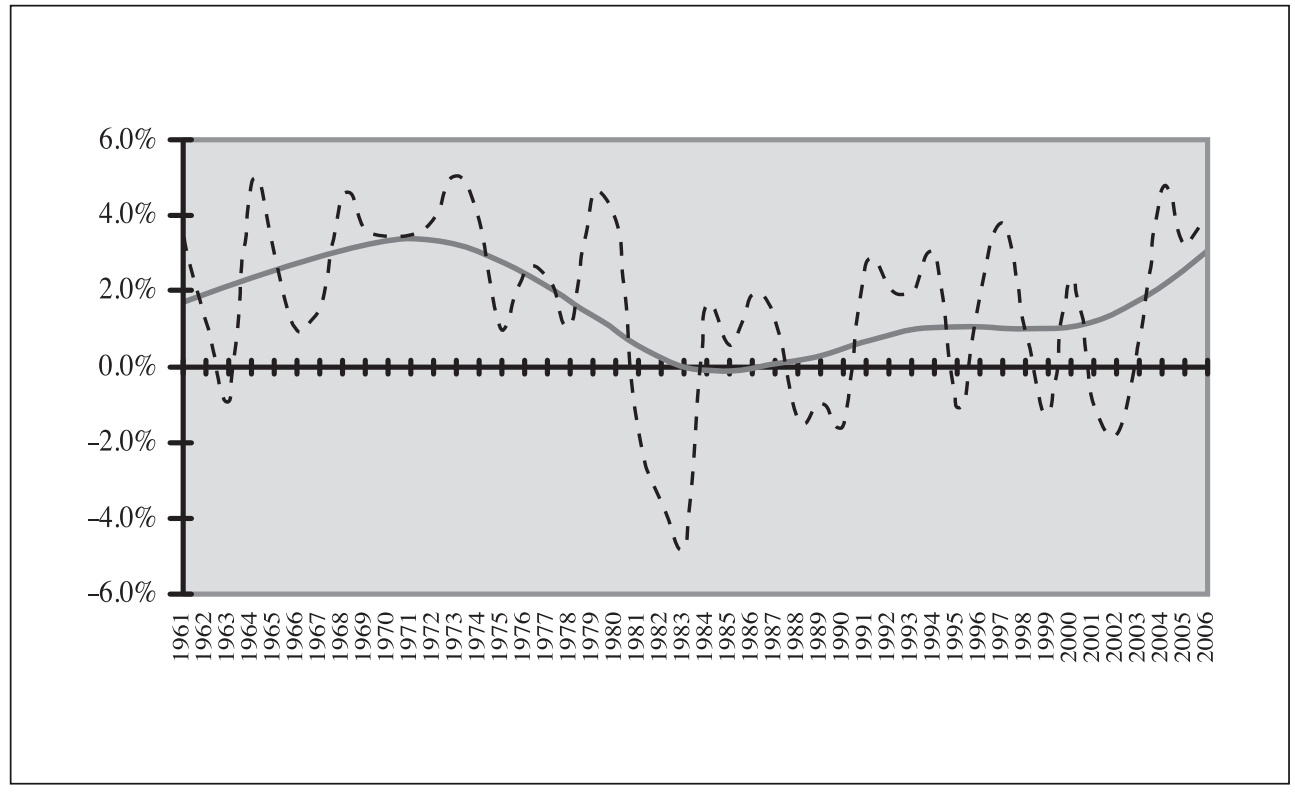

Source: Authors' elaboration, on the basis of World Development Indicators (2008).

More pointedly, notwithstanding progress in certain areas, some important structural characteristics of the Latin American economies have barely changed over the whole period of reforms. One of these is that the amount of manufacturing value added (MVA) per capita has remained almost constant over the last 25 years. Indeed, according to UNIDO figures, it is actually below the figure achieved at the end of the 1980s (Table 1). China, over the same period, managed to multiply by a factor of six its manufacturing production per capita. ${ }^{2}$

${ }^{2}$ It is worth noting that MVA is a good proxy for a number of other important indicators of development, being highly correlated both with the share of manufactured exports and technologicallymore advanced production. 
TABLE 1

PER-CAPITA MVA IN CONSTANT (1995) US \$

\begin{tabular}{|l|r|r|r|r|r|r|r|}
\hline Country group & 1981 & 1986 & 1989 & 1991 & 1995 & 2000 & 2005 \\
\hline Developed market economies & 4153 & 4444 & 4942 & 4942 & 5086 & 5699 & 5949 \\
\hline Transition economies & 655 & 721 & 723 & 723 & 450 & 540 & 814 \\
\hline Developing regions: & & & & & & & \\
\hline Sub-Saharan Africa & 32 & 32 & 31 & 31 & 28 & 29 & 30 \\
\hline North Africa & 128 & 152 & 156 & 156 & 159 & 185 & 197 \\
\hline Latin America and Caribbean & $\mathbf{8 0 7}$ & $\mathbf{7 0 1}$ & $\mathbf{6 6 9}$ & $\mathbf{6 6 9}$ & $\mathbf{6 8 7}$ & $\mathbf{7 3 1}$ & $\mathbf{7 6 9}$ \\
\hline South and East Asia & 92 & 113 & 164 & 164 & 214 & 260 & 329 \\
\hline China & 90 & 125 & 169 & 169 & 263 & 380 & 559 \\
\hline West Asia and Europe & 416 & 472 & 485 & 485 & 514 & 590 & 706 \\
\hline
\end{tabular}

Source: http://www.unido.org/data/UNIDO/Stats/Staworld2.cfm?c=GHA.

As a consequence of this apparent inability to raise manufacturing per capita, the share of manufacturing in GDP actually fell in the period between 1990-2004 (Table $2)$. In some countries, the scale of this de-industrialisation was really been quite pronounced. The explanation in some cases is obviously related to the boom in oil production or commodity production (countries like Ecuador, Venezuela or Bolivia), but there was also a quite clear trend towards de-industrialisation in countries like Uruguay, Jamaica and Panama. The share of manufacturing in GDP also declined in larger countries of the region like Brazil, Colombia and Mexico. This story is all the more surprising because of some notable cases of success in promoting manufacturing exports (as opposed to total value added) in the region, in countries such as Mexico, Brazil, the Dominican Republic, and Costa Rica (Agosin, 2006). In the case of Mexico, over the last two decades there has been a sharp shift in the composition of exports, from an extremely high dependence on natural resources (oil) towards a highly diversified export structure, in which more than 80 percent of exports are manufactures. Yet at the same time, manufacturing value added as a share of GDP over the same period has actually contracted, and the overall growth performance has been poor. Why such a dichotomous performance should occur is open to dispute, but might be associated with a slow 'maquilizacion' of the Mexican economy, whereby domestic industry is 'hollowed out' by a raising share of imported intermediates, and a subsequent collapse of the export multiplier (Mold and Rozo, 2006, Palma, 2005). Even in the case of Chile, successful export and growth performance since the mid-1980s has been accompanied by only weak structural change and diversification towards non-traditional exports. 
TABLE 2

MANUFACTURING SECTOR AS A SHARE OF GDP, 1990-2004

\begin{tabular}{|c|c|c|c|}
\hline & 1990 & 2004 & $\begin{array}{c}\text { Change } \\
1990-2006\end{array}$ \\
\hline Argentina & 23.9 & 22.3 & -1.7 \\
\hline Bolivia & 17.0 & 12.4 & -4.6 \\
\hline Brazil & 22.8 & 21.5 & -1.3 \\
\hline Chile & 17.0 & 17.0 & 0.0 \\
\hline Colombia & 18.0 & 14.4 & -3.6 \\
\hline Costa Rica & 20.4 & 19.6 & -0.8 \\
\hline Dominican Republic & 26.4 & 24.1 & -2.3 \\
\hline Ecuador & 19.4 & 4.7 & -14.7 \\
\hline El Salvador & 21.7 & 22.0 & 0.3 \\
\hline Honduras & 14.5 & 18.0 & 3.5 \\
\hline Jamaica & 18.6 & 12.5 & -6.0 \\
\hline México & 19.0 & 16.3 & -2.7 \\
\hline Panama & 12.9 & 7.2 & -5.6 \\
\hline Paraguay & 17.1 & 14.2 & -2.9 \\
\hline Peru & 18.2 & 14.9 & -3.3 \\
\hline Uruguay & 28.0 & 21.3 & -6.6 \\
\hline Venezuela & 27.2 & 17.1 & -10.1 \\
\hline Latin America and the Caribbean & 21.2 & 17.8 & -3.4 \\
\hline
\end{tabular}

Source: ECLAC database.

This raises the question of whether such phenomena are naturally-induced shifts towards the tertiary sector, or the result of policy failures. Commenting on the Chilean case, Mesquista Moreira (2007) argues that:

"Chile of the nineties is a "domestic" natural-resource success. Yet, Chile's success (which, by the way, still has close to 40 percent of its exports linked to one single product- 
copper) is dwarfed by the growth, diversification and technological sophistication of the "manufacturing" East Asia and is matched by Venezuela's failure, which bears clear symptoms of Dutch Disease...Trade liberalization and the hands-off policy that prevailed throughout the nineties led these economies to a regime as close to a "neutral" system of incentives as it has ever been. The "don't-turn-your-back" kind of advice does not seem to have, then, any practical consequence." (Mesquita Moreira, 2007)

Does this lack of diversification matter? At one level, the answer must be a resounding 'yes' - all highly specialised countries are poor, while developed countries tend to be highly diversified, both in their export and production structures (though there may be a point of inflection whereby high income countries also become more specialised) (Imbs and Wacziarg, 2003). There are some important theoretical reasons why greater diversification of export structure might lead to faster growth, including a decrease in the volatility of export income which is associated with an excessive dependence on commodity exports. This in turn could lead to more stable macroeconomic environment and faster growth. Similarly, more diverse economies may be better able to take advantage of export opportunities in global markets as they emerge (Agosin, 2006; UNIDO, 2009), a fact driven home by the observation that most trade expansion has been occurring at the extensive margin - that is through the expansion of new goods rather than greater trade of existing products (Hummels and Klenow, 2002).

In fact, in the 1960s and 70s under policies of import substitution a number of Latin American countries did achieve significant structural change in their domestic economies (Brazil, Mexico and Argentina being two notable examples), but their export structures remained to a large extent dependent on commodities. There is a general consensus in the literature that overvalued exchange rates (part and package of the import substitution policies, at least as they were applied in Latin America) contributed to this outcome (Bulmer Thomas, 2003, Rodrik, 2007). But subsequent policies from the mid-1980s onwards under the so-called New Economic Model (NEM) did little better in promoting structural change. With the overriding emphasis on controlling inflation, in many countries of the region tight monetary policies (sometimes including very damaging pegs of the currency) paradoxically led to a continuation of an overvaluation of the currency, with particularly damaging consequences for the perspectives of export diversification and manufacturing employment. ${ }^{3}$

According to other analysts, however, the lack of structural diversification and the observed trends towards deindustrialisation in the continent are nothing to be concerned about: they simply reflect a world-wide shift towards the service sector,

\footnotetext{
${ }^{3}$ In many countries trade liberalization occurred just as capital returned to Latin America. The net inflows pushed up the value of the real exchange-rate and encouraged imports, but not exports. This was the problem in Mexico from 1990 to 1994, in Argentina after 1991 and Brazil from 1994 to 1998. As a result, export performance in many countries was modest and Latin America's increasing share of world exports has mainly been due to Mexico (Bulmer Thomas, 2003: 369-70).
} 
something which is also evident in the industrialised countries. In the United States, for example, the service sector now accounts for around 70 per cent of the economy, yet this development apparently worries few people. To borrow Krugman's phrase, the economy is becoming increasingly 'light'.

The practical repercussions of these sectoral shifts have been much debated. In employment terms, the impact is generally considered to have been negative - manufacturing firms have a greater employment-generating potential than the service sector, not only through the direct employment deriving from the initial investment, but also through the "spillovers" into the rest of the economy via forward and, especially, backward linkages. ${ }^{4}$ Given their contribution to the exportable sector, a lack of dynamism in manufacturing can also have a negative impact on the trade balance, with countries displaying a weak manufacturing sector often also reporting poor balance of payments results. ${ }^{5}$ Services, on the other hand, are only partially tradeable, and may not be able to offset the fall in manufacturing exports. ${ }^{6}$ And precisely because of their tradeability, manufactured goods are open to the full-force of international competition, thus making them more likely to innovate. Not surprisingly, productivity growth is typically higher in manufacturing than in services (Figure 2).

As Mulder (2002:23) points out, however, the view that services have little potential for labour productivity increases may be too pessimistic and simplistic, for productivity gains have been achieved in several service industries. Wolff (2007: 15) notes that standardized services like transportation, communications, and utilities can behave very much like goods industries in terms of productivity performance. And the introduction of revolutionary new technology such as that of information and communications technology (ICT) could lead to certain service sectors (e.g. telecommunications, business services or finance) replacing or complementing manufacturing as a new or as an additional engine of growth (Dasgupta and Singh, 2005: 436).

To sum up, while the evidence is more circumstantial than conclusive, there are still reasons to be concerned about the trend towards deindustrialization in Latin America. In a classification of countries according to growth performance and level of manufacturing value added a UNIDO (2009) study observes that in the fast growing low-income countries, the rate of manufacturing value-added growth per

\footnotetext{
${ }^{4}$ In view of the standard perception of the service sector as being characterised by labour-intensive activities such as hotels, restaurants and the retail trade, this may initially seem a rather surprising. But in fact the bulk of investment in service industries creates relatively few employment opportunities. Public utilities (e.g. the telecommunications sector), for example, are particularly capital intensive. Likewise, financial services are intensive in their use of financial capital and technology.

${ }^{5}$ See, for instance, Cairncross (1978), who associates Britain's balance of payments difficulties to the poor performance of British manufacturing sector in the post-War period.

${ }^{6}$ Technological advances have changed things somewhat, and now many services that were not previously tradeable have become so - telephone call centres located in other continents being one example, facilitated by rapidly falling costs in telecommunications (itself a service industry).
} 
FIGURE 2

LABOUR PRODUCTIVITY GROWTH BY SECTOR, BRAZIL, MEXICO AND THE USA, 1950-96 (AVERAGE ANNUAL COMPOUND GROWTH RATES)

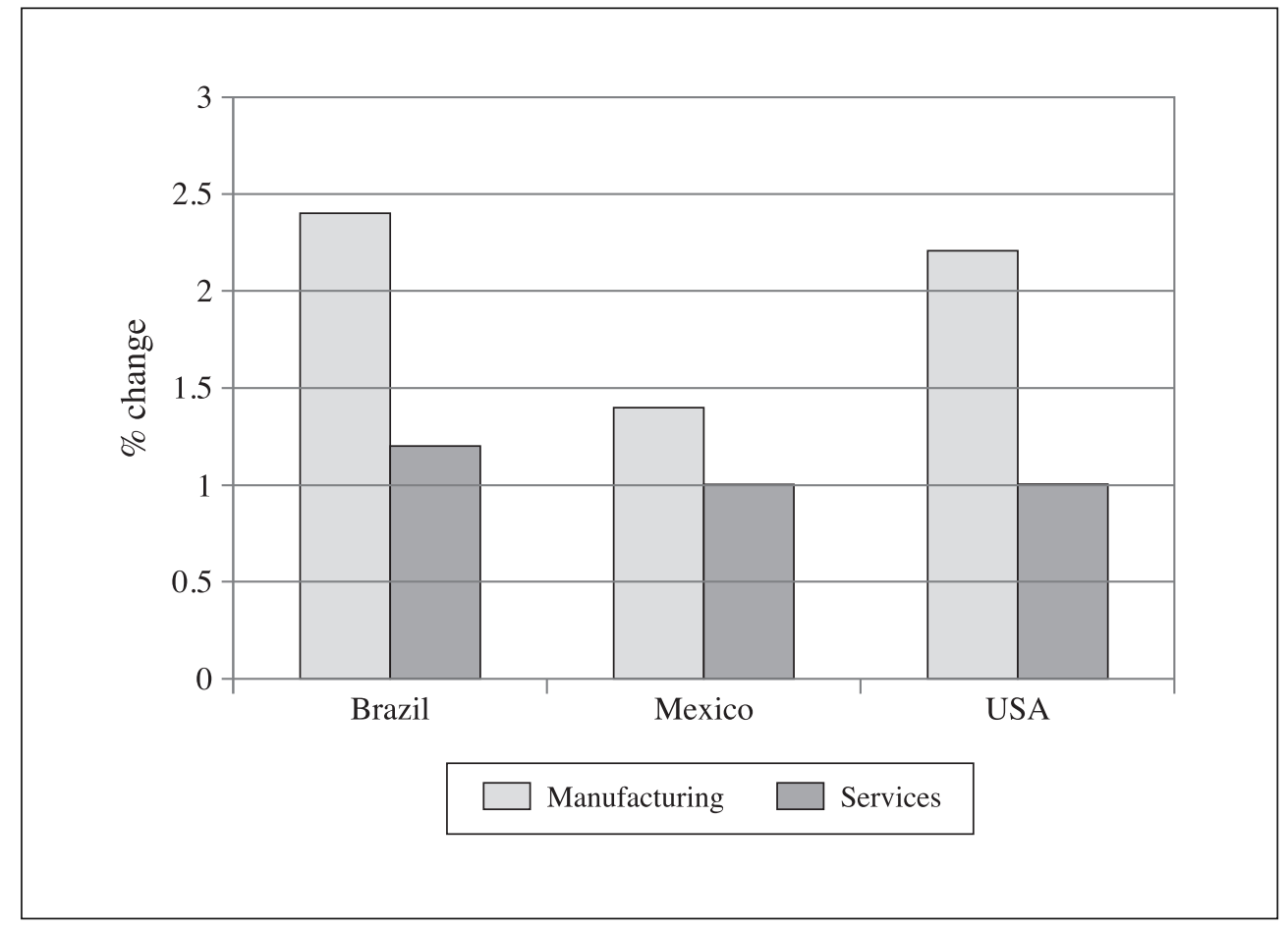

Source: Mulder (2002: 23).

worker was about twice as fast in the slow growers, while it was more than three times as fast in per capita terms. But the figures were even more striking for middle income countries (a more relevant case for Latin America): MVA per capita grew seven times faster in the fast-growing group of countries. As UNIDO (op. cit., 6) notes, "these large differences support the view that changes in manufacturing productivity are driving economy-wide growth, and not the other way around." Moreover, at the level of per capita incomes prevailing in the low and middle-income countries, the income elasticity of demand for manufactures continues to be very high. The lesson would appear to be that countries ignore the development of their manufacturing sectors at their peril. That said, our brief review of the literature suggests that there are also strong a priori reasons to suppose that certain parts of the services sectors fulfil requirements of dynamic sectors in the Kaldorian sense, and could therefore be regarded as an additional engine of growth (Dasgupta and Singh, 2005). In the empirical analysis that follows, we will test this proposition. 


\section{The Empirical Analysis - Methodological Considerations}

Nicholas Kaldor formulated his well known three growth 'laws' within a developed country context, being initially formulated to explain the slow rate of growth in the United Kingdom (Kaldor, 1966). Although this paper only tests the first of those three laws, all three are interrelated, and thus a brief explanation is in order (for a more complete discussion, see Rowthorn, 1975, Kaldor, 1975 and Thirlwall, 2002). Kaldor's first growth law is that there exists a strong causal relation between the growth of manufacturing output and the growth of GDP. The second law states that there exists a strong positive causal relation between the growth of manufacturing output and the growth of productivity in manufacturing as a result of static (increasing returns to scale) and dynamic (learning-by-doing) returns to scale. This is also known as Verdoorn's Law. The third law states that there is a strong positive causal relation between the rate at which the manufacturing sector expands and the growth of productivity outside the manufacturing sector because of diminishing returns in agriculture and many 'petty' service activities which supply labour to the industrial sector.

Expressed algebraically, then, Kaldor's first law states that

$$
q_{\mathrm{i}}=c_{1}+b_{\mathrm{i}} q_{\mathrm{gls}}
$$

where

$$
\begin{aligned}
& q_{\mathrm{i}}=\text { growth of output (gross domestic product); and } \\
& q_{\mathrm{gls}}=\text { growth of the 'leading sector' }
\end{aligned}
$$

The observed relationship is however open to criticisms on several grounds. Firstly, ordinary least squares regression estimates are unreliable in models where the alleged independent variable (in Kaldor's law) is not truly independent or predetermined. This is of course inevitably the case when $q_{\mathrm{gls}}$ is a sub-set of $q_{\mathrm{i}}$ (i.e. growth in the manufacturing sector contributes to overall economic growth). Partly in response to this criticism, a different kind of test has been put forward, and that is to regress $q_{\mathrm{i}}$ on growth of the leading sector minus all the other sectors. Specified in this way, there is no overlap of dependent and independent variables. In other words,

$$
q_{\mathrm{os}}=c_{1}+b_{1}\left(q_{\mathrm{gls}}\right)
$$

That is, the rate of growth is a function of the difference between the rate of growth of the leading sector $\left(q_{\mathrm{gls}}\right)$ and that of all other sectors $\left(q_{\mathrm{os}}\right)$, where $q_{\mathrm{os}}$ is defined as $\left(q_{\mathrm{i}}-q_{\mathrm{gls}}\right)$. This is the basic specification that we will use in our econometric analysis. 
Secondly, another methodological weakness of some previous analyses on the validity of Kaldor's first law is that they fail to compare results across different sectors - focusing on the manufacturing sector, a high $\mathrm{R}^{2}$ and/or large parameter estimate are taken as evidence in favour of the 'manufacturing sector as the engine of growth' hypothesis. Yet to be in anyway meaningful, such analysis needs to be based on comparisons with other sectors. In this paper, we compare the results for manufacturing with those for other sectors (agriculture, mining, services and its subsectors of finance, transport, retail trade, etc.).

The econometric analysis was carried out on a panel of 18 Latin American countries $^{7}$, over the period 1951-2006.). Data was drawn from the ECLAC. The initial analysis is on the basis of four major sectoral divisions - manufacturing, services, mining and agriculture. An important issue to be borne in mind in this kind of analysis is the poolability of the data. While sharing some basic underlying characteristics, the economies of the region display great diversity, both in terms of income per capita, industrial structure, and leading economic activities. In order to control for this, all regressions are carried out using fixed-effects, on the a priori assumption that the Latin American countries may display behavioural differences to the whole population of countries (the implication of using a random effects estimator - see Hsiao, 1986: 42). ${ }^{8}$

One further point to be borne in mind is the temporal dimension of the analysis. The dataset used in this paper include data from 1950-2006. Structural change over such long periods of time is likely to exert a major influence on parameter estimates. In other words, parameters cannot be assumed to be constant over such a long-run analysis. To control for this, the analysis here includes structural dummies, based on a literature review of the reform dates for the application of the NEM (Table 3). ${ }^{9}$ An autoregressive lag is utilized to control for serial correlation.

${ }^{7}$ Countries included in the analysis were Argentina, Bolivia, Brazil, Chile, Colombia, Costa Rica, Ecuador, El Salvador, Guatemala, Honduras, Mexico, Nicaragua, Panama, Peru, Paraguay, the Dominican Republic, Uruguay and Venezuela.

${ }^{8}$ Because country specific characteristics are likely to be highly correlated with other regressors in a macro data set, where they are considered as omitted variable (Wooldridge, 2002), fixed effects are preferable to random effects. Based on a Monte Carlo simulation for macro-panels with small dimensions, Judson and Owen (1999) find that the lowest bias of the estimated coefficients is obtained with this corrected LSDV estimator. The choice of a FE estimator was confirmed by the application of a Haussman test.

${ }^{9}$ None of the dates can of course be considered definitive - and often there is an enormous difference between announcing and actually applying reforms. Andrews-Quandt tests (an advanced application of Chow-tests for structural breaks) were also tried on the whole period. Rarely, however, did the structural breaks identified coincide with the breaks in policies identified in the literature review. This is not so surprising - the countries studied often suffered great volatility in their growth rates for reasons other than policy reform - the frequency of coup d'etats for example. Structural breaks were also detected in several countries during the first and second oil crises. In any case, as a post-hoc method, this method was considered less satisfactory than the ex-ante rationale of attempting to control for major policy shifts. 
TABLE 3

DATES FOR START OF REFORM PERIOD

\begin{tabular}{|l|l|l|l|}
\hline Argentina & 1991 & Guatemala & 1988 \\
\hline Bolivia & 1985 & Honduras & 1992 \\
\hline Brazil & 1990 & Mexico & 1986 \\
\hline Chile & 1975 & Nicaragua & 1991 \\
\hline Colombia & 1991 & Panama & 1995 \\
\hline Costa Rica & 1986 & Peru & 1990 \\
\hline Dominican Republic & 1990 & Paraguay & 1989 \\
\hline Ecuador & 1992 & Uruguay & 1978 \\
\hline El Salvador & 1989 & Venezuela & 1989 \\
\hline
\end{tabular}

Source: Elaborated from Thorp (1998:228-229), Bulmer Thomas (2003) and Cimoli and Correa (2005: 52).

\section{a) Results - Fixed Effects Estimator}

Equation (2) above was estimated for the four major 'leading sectors' (manufacturing, agriculture, mining and services) firstly using the static fixed effects model. ${ }^{10}$ The results are shown in Table 4.

It is notable that while there is an apparently strong relationship between manufacturing growth and total economy-wide output (as predicted by Kaldor's law), there is even a stronger association between service sector growth and output. The results suggest that the highest elasticities are in manufacturing and services ( 0.73 and 0.91 respectively). It is also notable that neither mining nor agricultural sectors seem to be highly associated with broader economic growth - a finding which to some extent revindicates the traditional predilection among Latin American academics and policymakers to reduce the dependence of their economies on the primary sectors (something which, as noted earlier, has not been achieved in practice). One further observation is that while the dummy variable for policy reform is significantly positive for the manufacturing sector, it is negative for both agriculture and mining, suggesting that in these cases the reforms diminished still further the weak impact of growth of these sectors on overall economic growth (the dummy can be interpreted in the broadest sense as evidence of the reforms on spillovers from one sector to the rest).

${ }^{10}$ Sectoral definitions are manufacturing (MAN), agriculture (AGR), mining (MIN) and services (SER) with the prefix NON- meaning that it is the growth rate of the rest of the economy $q_{\mathrm{os}}$. 
TABLE 4

STATIC PANEL RESULTS - MAJOR PRODUCTIVE SECTORS

\begin{tabular}{|c|c|c|c|c|}
\hline & NONMAN & NONAGR & NONMIN & NONSER \\
\hline C & 1.9834 & 3.8759 & 4.1412 & 0.2002 \\
\hline MAN & 11.2935 & 14.0799 & 16.0069 & 0.8417 \\
\hline & 0.4081 & & & \\
\hline AGR & 25.4699 & & & \\
\hline MIN & & 0.1756 & & \\
\hline SER & & 6.8559 & & \\
\hline & & & 0.0017 & \\
\hline & & & 0.7859 & \\
\hline DUMMY & 0.4939 & -0.8055 & -0.7211 & 0.2970 \\
\hline AR(1) & 1.8880 & -1.8773 & -1.7406 & 0.9931 \\
\hline & 0.2047 & 0.3243 & 0.3256 & \\
\hline Adjusted R-squared & 0.3859 & 10.3380 & 10.1925 & \\
\hline Log likelihood & $-2,355.6$ & $-2,684.7$ & $-2,509.3$ & $-2,517.4$ \\
\hline F-Statistic & 271.06 & 64.12 & 37.35 & 282.94 \\
\hline Durbin-Watson & 1.98 & 1.98 & 1.97 & 1.90 \\
\hline Elasticity* & 0.73 & 0.13 & 0.00 & 0.91 \\
\hline N. Obs & 929 & 929 & 885 & 877 \\
\hline Sample & $1951-2006$ & $1951-2006$ & $1951-2006$ & $1951-2006$ \\
\hline
\end{tabular}

* Elasticities were calculated around the means of the dependent and independent variables. $T$ values are shown under the parameter estimates.

Source: Authors' elaboration.

One of the problems with the analysis above is that under the label of services sector is the largest single group of activities - accounting for between 50-60 per cent of GDP. As a consequence, a high correlation between service sector growth and the rest of the economy is hardly surprising. ${ }^{11}$ In the following analysis, we breakdown the services sector into several sub-sectors. ${ }^{12}$ The results of the regressions

11 Note that this problem is significantly more serious than in the case of manufacturing, which typically is responsible for only 15-20 percent of GDP in countries in the region.

${ }^{12}$ In Latin America, the analysis is much complicated by a large informal sector. Most (though not all) informal sector activities would be classified as services. But this risks making the service sector a 'catch-all' residual for all activities not classified as either industry or primary. According to some authors (e.g. de Soto, 1989, OECD, 2009), the informal sector represents an important source of dynamism. 
on the sub-divisions of the service sector are shown in Table 5. ${ }^{13}$ As was anticipated, for the smaller sub-sectors, the estimated elasticities are somewhat lower than for the whole of the service sector. As reported in Table 5, none are higher than that for the manufacturing sector $(0.73)$. The weakest impact on overall growth is from public, social and personal services, with an elasticity of only 0.15 .

TABLE 5

STATIC PANEL RESULTS - SERVICE SECTOR SUBDIVISIONS

\begin{tabular}{|c|c|c|c|c|}
\hline & NONCOM & NONTRANS & NONFIN & NONSOC \\
\hline \multirow[t]{2}{*}{$\mathrm{C}$} & 2.5886 & 2.8042 & 2.5517 & 3.3900 \\
\hline & 16.3021 & 12.0530 & 8.5984 & 11.0903 \\
\hline \multirow[t]{2}{*}{$\mathrm{COM}$} & 0.3655 & & & \\
\hline & 22.1370 & & & \\
\hline \multirow[t]{2}{*}{ TRANS } & & 0.2091 & & \\
\hline & & 12.0589 & & \\
\hline \multirow[t]{2}{*}{ FIN } & & & 0.3019 & \\
\hline & & & 9.3728 & \\
\hline \multirow[t]{2}{*}{ SOC } & & & & 0.1633 \\
\hline & & & & 4.6706 \\
\hline \multirow[t]{2}{*}{ DUMMY } & -0.4868 & -0.7772 & -0.2030 & -0.1864 \\
\hline & -1.9998 & -2.2243 & -0.5068 & -0.4212 \\
\hline \multirow[t]{2}{*}{$\mathrm{AR}(1)$} & & 0.2213 & 0.2144 & 0.2352 \\
\hline & & 6.6106 & 5.8162 & 7.0389 \\
\hline Adjusted R-squared & 0.3575 & 0.2281 & 0.1800 & 0.0967 \\
\hline Log likelihood & $-2,375.4$ & $-2,391.6$ & $-2,219.8$ & $-2,571.8$ \\
\hline F-Statistic & 249.1903 & 85.7058 & 57.2599 & 31.6895 \\
\hline Durbin-Watson & 1.80 & 1.99 & 1.98 & 2.01 \\
\hline Elasticity* & 0.37 & 0.31 & 0.33 & 0.15 \\
\hline N. Obs & 893 & 861 & 770 & 861 \\
\hline Sample & 1950-2006 & $1951-2006$ & $1951-2006$ & $1951-2006$ \\
\hline
\end{tabular}

* Elasticities were calculated around the means of the dependent and independent variables. $T$ values are shown under the parameter estimates.

Source: Authors' elaboration.

${ }_{13}$ The sectoral definitions in this case are retail and wholesale trade, restaurants and hotels (COM), transport, warehousing and communications (TRANS), financial institutions, insurance, real estate and business services (FIN) and public, social and personal services (SOC). As before, the prefix NON denotes with the growth rate of the rest of the economy $q_{\mathrm{os}}$. 


\section{b) Dynamic analysis}

The relationships between the sectoral and overall rates of growth were further examined through the use of the Generalised Method of Moments (GMM) for dynamic panel data and the use of state space econometric methodology. ${ }^{14}$ The choice of technique responded to three types of considerations. Dynamic panel data addresses the first two and the state space model simulation deals with the third one. Firstly, the rate of growth may exhibit inertia and as a result should be modelled as dependent on its past values. Secondly, the explanatory variable, the sectoral rate of growth, may actually be influenced by the rate of growth of the economy, and as a result is also an endogenous variable. To control for this phenomenon of reverse causality, the sectoral and overall rate of growth of the economy should be determined simultaneously. Finally, it is to be noted that the coefficients computed under standard static techniques can actually vary over time. State space techniques can capture the evolution of the coefficient through time. ${ }^{15}$

The dynamic panel technique GMM technique proposed by Arellano and Bond (1991) consists in taking the first differences of a model which allows for the existence of a $k$ number of lags of the dependent variable. To control for the possible correlation between the dependent variable and the error term, Arellano and Bond propose the use of the past value of the dependent variable and of the explanatory variables as instruments. Thus the GMM estimator produces unbiased and consistent estimates of the regressors as long as the instruments identified are valid instruments. To this end the econometric estimation should meet two conditions. First, the error term should not be correlated so that the estimates are not biased. Second, the explanatory variables must be weakly exogenous (or which is the same thing be valid instruments). Both of these conditions are addressed through an AR test and the Sargan test.

In order to throw further light on the relationship between the sectoral and overall rates of growth but from a long-run perspective, dynamic panel cointegration tests were carried out. Cointegration testing within a dynamic panel analysis avoids the difficulties inherent to static cointegration analyses as well as the sensitivity problems of time series methods (Kelly and Mavrotas, 2003). More importantly these techniques

${ }^{14}$ In a further exploration of the dynamic nature of the underlying relationships, the authors also ran Vector Autoregressive (VAR) estimations of equation (2). However, while the coefficients were similar to the reported values here, the lagged values were not significant, and hence the results are not reported in this paper.

${ }^{15}$ Formally, in the general case a state space model representation for an $n \times 1$ vector $y_{t}$, comprises two equations.

(1) $y_{t}=Z_{t} \alpha_{t}+c_{t}+\varepsilon_{t}$

(2) $\alpha_{t}=d_{t}+T_{t} \alpha_{t-1}+v_{t}$

where $Z_{t}$ is a conformable matrix, associated to the $(\mathrm{mx} 1)$ vector of unobserved state variables $\alpha_{t} . T_{t}$ is a matrix of parameters; $d_{t}$ and $c_{t}$ are vectors that include exogenous and observable variables. The error terms $\varepsilon_{t}$ and $v_{t}$ have the usual assumptions. By construction the (mx1) vector of unobserved state variables $\alpha_{t}$ follows an autoregressive process of the first order. The most used algorithm to estimate the parameters of Eqs. (1) and (2) is the Kalman filter. 
allow for existing heterogeneity in coefficients and dynamics across countries which are bound to be present in the Latin American context as different countries exhibit markedly different sizes and heterogeneous sectoral structures. As in the case with time series, testing for cointegration requires that the series in question have the same order of integration. In the dynamic panel context, the orders of integration are established through three standard tests. These are the Levin and Lin (1993), Im et al. (1997) and Maddala and Wu (1999). ${ }^{16}$ The existence of cointegration

TABLE 6

DYNAMIC PANEL - MAJOR SECTORS

\begin{tabular}{|c|c|c|c|c|}
\hline & NONMAN & NONAGR & NONMIN & NONSER \\
\hline \multirow[t]{2}{*}{ MAN } & 0.5144 & & & \\
\hline & 4.7685 & & & \\
\hline \multirow[t]{2}{*}{ NONMAN $(-1)$} & 0.1564 & & & \\
\hline & 1.3532 & & & \\
\hline \multirow[t]{2}{*}{ AGR } & & 0.3122 & & \\
\hline & & 10.8724 & & \\
\hline \multirow[t]{2}{*}{ NONAGR $(-1)$} & & 0.2589 & & \\
\hline & & 14.6449 & & \\
\hline \multirow[t]{2}{*}{ MIN } & & & 0.0101 & \\
\hline & & & 2.6417 & \\
\hline \multirow[t]{2}{*}{ NONMIN $(-1)$} & & & 0.2482 & \\
\hline & & & 4.5163 & \\
\hline \multirow[t]{2}{*}{ SER } & & & & 0.8160 \\
\hline & & & & 106.7390 \\
\hline \multirow[t]{2}{*}{ NONSER $(-1)$} & & & & -0.0190 \\
\hline & & & & -4.5253 \\
\hline \multirow[t]{2}{*}{ DUMMY } & 0.9929 & -1.3209 & -1.3280 & -0.6758 \\
\hline & 1.2995 & -4.0043 & -2.2370 & -10.1024 \\
\hline Wald test $(\beta=0)$ & 22.7 & 118.2 & 6.98 & 11393 \\
\hline Sargan test-p value & 0.44 & 0.41 & 0.35 & 0.58 \\
\hline Cointegration test & 295.4 & 324.2 & 265.8 & 269.14 \\
\hline Elasticity* & 0.92 & 0.23 & 0.02 & 0.92 \\
\hline N. obs & 911 & 911 & 869 & 841 \\
\hline Sample & $1952-2006$ & $1952-2006$ & $1952-2007$ & $1952-2006$ \\
\hline
\end{tabular}

* Elasticities were calculated around the means of the dependent and independent variables.

$T$ values are shown under the parameter estimates.

Source: Authors' elaboration.

${ }^{16}$ Levin and Lin (1993) assume that the lagged dependent variable is homogenous across counties. Im et al. (1997) allow for testing whether the homogeneous lagged dependent variable hypothesis is indeed a valid one. Maddala and Wu (1999) has shown to have more robust properties and better performance than the first two. In particular it is said to be "robust to statistical choice, lag length in the unit root regressions and varying time dimensions for each cross-sectional unit." 
between $q_{\mathrm{gds}}$ and $\left(q_{\mathrm{gds}}-q_{\mathrm{os}}\right)$ are determined on the basis of the Larsson et al. (1998) test which is based on Johansen's (1988) procedure.

The data confirms in all cases the existence of a cointegrating relationship (Table 6), thus validating the choice of estimation techniques. The Sargan test indicates the validity of the instruments and the absolute value of the coefficient of the lagged dependent variables is greater than 1 which indicates that the model is stable. The major change in the parameter estimates is that the elasticity of manufacturing to total growth is considerably higher than in the static results $(0.92$ versus 0.73$)$. The elasticity for the agricultural sector also considerably higher ( 0.23 versus 0.13$)$, though still low in comparison with other sectors.

The analysis at the country level using state space techniques shows that the importance of the manufacturing sector to act as the 'leading' or 'motor' sector of the economy varied widely among Latin American economies (Figure 3). Some South American economies such as Ecuador, Bolivia, Colombia and Peru show some of the lowest values for the regression coefficient of manufacturing on the non-manufac-

FIGURE 3

\section{LATIN AMERICA. FINAL VALUE OF STATE SPACE COEFFICIENT FOR THE REGRESSION OF MANUFACTURING ON NON-MANUFACTURING SECTORS OF THE ECONOMY. 1970-2006}

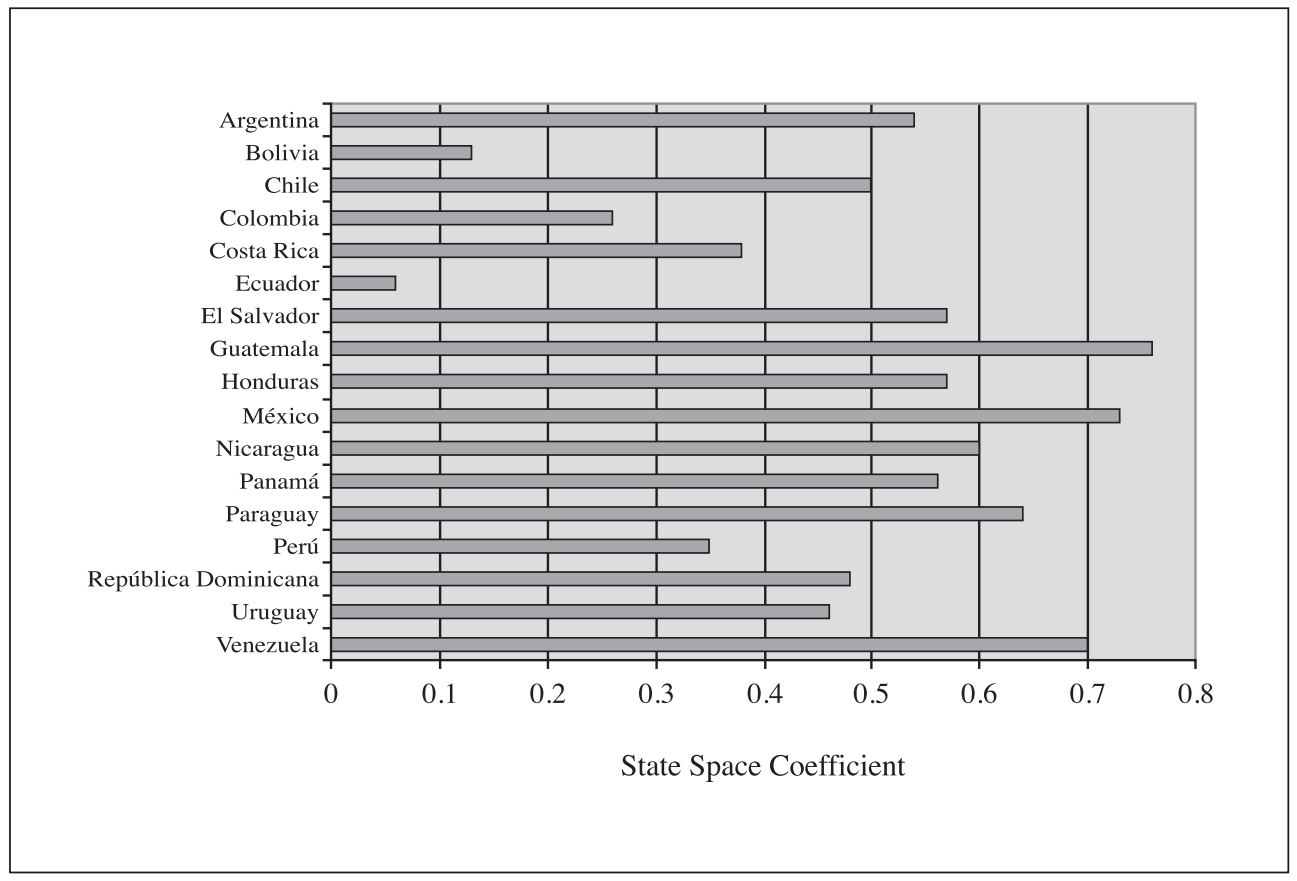

Note: All coefficients are significant at the $95 \%$ level of confidence.

Source: Authors' elaboration. 
turing sectors of the economy $(0.06,0.13,0.26$ and 0.35 respectfully). Contrarily some of the Central American economies (in particular Guatemala), Mexico and Venezuela, show the highest degree of interdependence between the manufacturing and non-manufacturing sectors of the economy. The respective coefficients of Guatemala, Mexico and Venezuela are $0.76,0.73$ and 0.70 .

The cases of Ecuador, Colombia and Bolivia reflect in part on-going processes of deindustrialization and partly a growing productive specialization in the nonmanufacturing sector of the economy due to favourable conditions in the production of oil and metals (such as in the case of Ecuador or Bolivia). The evolution over time of their respective coefficients shows a downward trend in the cases of Ecuador and Colombia, and a stagnant coefficient for Bolivia (Figure 4).

FIGURE 4

BOLIVIA, COLOMBIA AND ECUADOR. EVOLUTION OF STATE SPACE COEFFICIENT FOR THE REGRESSION OF MANUFACTURING ON NON-MANUFACTURING SECTORS OF THE ECONOMY. 1970-2006

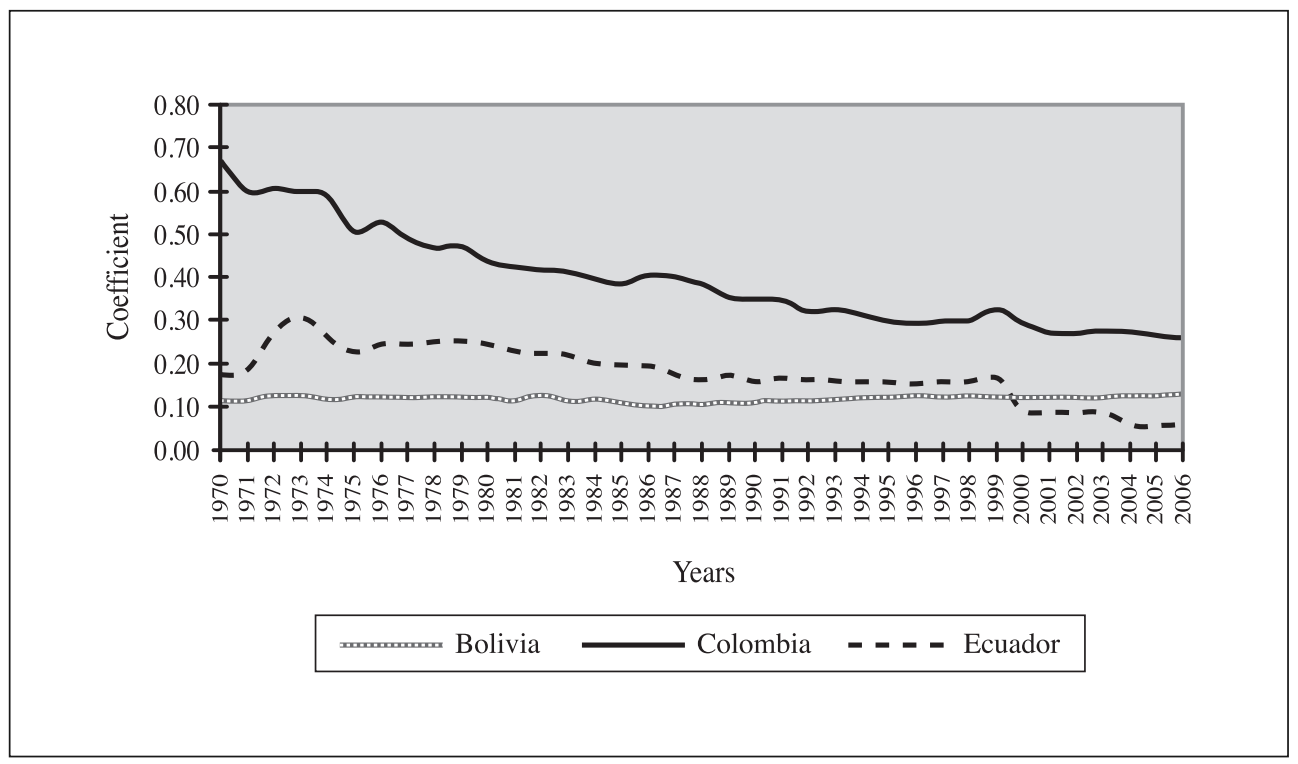

Source: Authors' elaboration.

For their part, with the exception of Guatemala, the cases of Central America countries also show a process of decline of importance or stagnation in the manufacturing sector to act as the leading sector of overall economic growth. This may be explained by the fact that most their manufacturing production takes place within the realm of free trade zones which have weak linkages with the rest of the economy (Figure 5). 


\section{FIGURE 5}

COSTA RICA, EL SALVADOR, GUATEMALA AND NICARAGUA.

EVOLUTION OF STATE SPACE COEFFICIENT FOR THE REGRESSION

OF MANUFACTURING ON NON-MANUFACTURING SECTORS

OF THE ECONOMY. 1970-2006

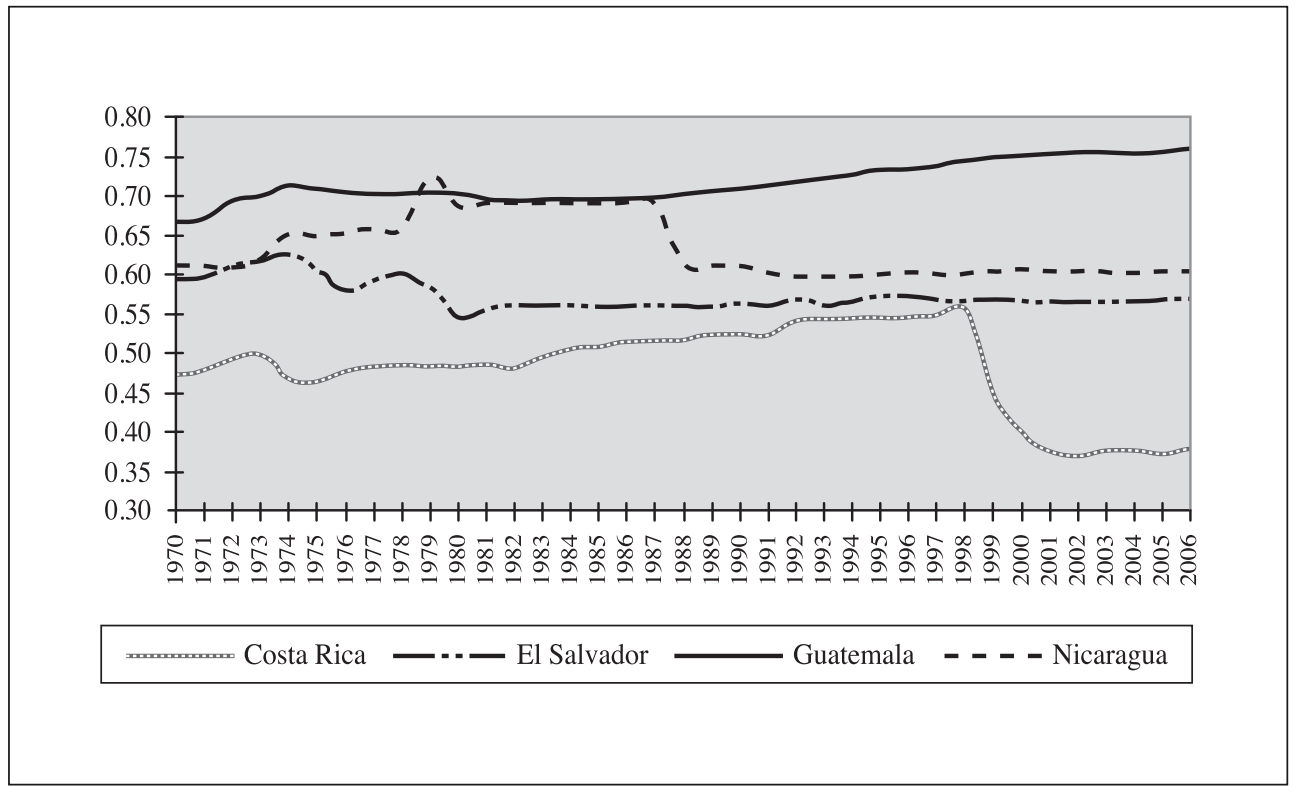

Source: Authors' elaboration.

\section{c) Disaggregated Analysis of the Service Sector}

In view of the evident importance of service sector growth on economy-wide output, the same GMM technique was applied to the data for the sub-sectors of services, with similar results although the size of the elasticities are smaller for the service subdivisions than for services as a group (Table 7).

The analysis at the country level using state space techniques to determine the importance of the disaggregated services sectors reinforces the results produced previously (Table 8). Indeed, the estimated elasticities are, generally speaking, considerably higher than in the case of the dynamic panel estimates. There are a wide variety of results according to country, but particularly notable is the divergence in results with public, social and personal services sector. Here it has to be borne in mind that we are talking about growth rates of the individual sectors. So differences between countries may reflect not only efficiency in public expenditures but also the level of public expenditure. 
TABLE 7

DYNAMIC PANEL - SERVICE SECTOR SUBDIVISIONS

\begin{tabular}{|c|c|c|c|c|}
\hline & NONCOM & NONTRANS & NONFIN & NONSOC \\
\hline \multirow[t]{2}{*}{$\mathrm{COM}$} & 0.4366 & & & \\
\hline & 28.6607 & & & \\
\hline \multirow[t]{2}{*}{$\operatorname{NONCOM}(-1)$} & 0.0473 & & & \\
\hline & 1.4526 & & & \\
\hline \multirow[t]{2}{*}{ TRANS } & & 0.3061 & & \\
\hline & & 9.2858 & & \\
\hline \multirow[t]{2}{*}{ NONTRANS $(-1)$} & & 0.1951 & & \\
\hline & & 5.7028 & & \\
\hline \multirow[t]{2}{*}{ FIN } & & & 0.4619 & \\
\hline & & & 127.2774 & \\
\hline \multirow[t]{2}{*}{ NONFIN (-1) } & & & 0.0863 & \\
\hline & & & 16.8995 & \\
\hline \multirow[t]{2}{*}{ SOC } & & & & 0.3158 \\
\hline & & & & 4.4175 \\
\hline \multirow[t]{2}{*}{ NONSOC $(-1)$} & & & & 0.1727 \\
\hline & & & & 10.8110 \\
\hline \multirow[t]{2}{*}{ DUMMY } & -0.8211 & -0.7874 & -0.6135 & -0.6492 \\
\hline & -3.6489 & -1.3395 & -13.8290 & -1.8332 \\
\hline Wald test $(\beta=0)$ & 821.4 & 86.22 & 1699.5 & 19.51 \\
\hline Sargan test-p value & 0.49 & 0.40 & 0.54 & 0.29 \\
\hline Cointegration test & 269.1 & 341.9 & 247.5 & 252.2 \\
\hline Elasticity* & 0.44 & 0.45 & 0.51 & 0.29 \\
\hline N. Obs & 859 & 844 & 753 & 844 \\
\hline Sample & $1952-2004$ & $1952-2005$ & $1952-2006$ & 1952-2006 \\
\hline
\end{tabular}

* Elasticities were calculated around the means of the dependent and independent variables.

$T$ values are shown under the parameter estimates.

Source: Authors' elaboration. 
TABLE 8

LATIN AMERICA.

RESULTS OF COMMERCIAL, TRANSPORT, FINANCIAL AND SOCIAL SERVICES. (1950-2006)

\begin{tabular}{|l|c|c|c|c|}
\hline \multirow{2}{*}{\multicolumn{1}{|c}{ Countries }} & \multicolumn{4}{|c|}{ Final State Space coefficients } \\
\cline { 2 - 5 } & Commercial & Transport & Financial & SOC \\
\hline Argentina & $0.59(16.9)$ & $0.86(15.50)$ & $0.63(5.56)$ & $1.56(7.65)$ \\
\hline Bolivia & $0.09(1.56)$ & $0.21(4.50)$ & $0.12(1.50)$ & $-0.08(-1.24)$ \\
\hline Chile & $0.49(8.95)$ & $0.65(12.45)$ & $0.30(3.98)$ & $1.01(5.72)$ \\
\hline Colombia & $0.65(13.33)$ & $0.63(13.34)$ & $0.67(12.13)$ & $-0.28(-2.50)$ \\
\hline Dominican Republic & $0.55(12.52)$ & $0.55(11.47)$ & $0.73(5.20)$ & $0.70(5.31)$ \\
\hline Ecuador & $0.69(6.58)$ & $0.63(7.38)$ & $0.53(5.64)$ & $0.53(3.98)$ \\
\hline El Salvador & $0.16(2.28)$ & $0.62(12.98)$ & $0.52(3.98)$ & $0.06(0.58)$ \\
\hline Guatemala & $0.42(6.89)$ & $-0.10(-2.64)$ & $-0.09(-1.46)$ & $0.13(1.61)$ \\
\hline Honduras & $0.50(5.86)$ & $0.66(7.46)$ & $0.50(5.59)$ & $0.35(4.83)$ \\
\hline Mexico & $-0.11(-1.99)$ & $0.64(12.70)$ & $0.79(7.59)$ & $1.01(14.16)$ \\
\hline Nicaragua & $0.64(11.67)$ & $0.42(5.87)$ & $0.77(8.03)$ & $0.90(8.12)$ \\
\hline Panama & $0.57(8.93)$ & $0.09(2.75)$ & $0.55(6.89)$ & $0.66(5.17)$ \\
\hline Paraguay & $0.13(1.76)$ & $0.11(1.93)$ & $0.08(0.33)$ & $0.03(0.35)$ \\
\hline Peru & $0.40(3.05)$ & $0.43(2.68)$ & $0.40(0.73)$ & $0.83(5.25)$ \\
\hline Uruguay & $0.24(4.73)$ & $0.51(8.41)$ & $0.06(0.37)$ & $-0.56(-5.5)$ \\
\hline Venezuela & $0.49(9.84)$ & $0.56(7.80)$ & $0.66(7.35)$ & $0.59(6.87)$ \\
\hline
\end{tabular}

Note: Z-statistics in parenthesis

Source: Authors' elaboration.

\section{Conclusions}

The aim of this paper has been to trace empirical regularities in the patterns of growth in Latin America and identify the 'leading sectors' over the long run. Although originally postulated in the context of the industrial economies, Kaldor's first growth law provide a useful framework for carrying this out. Our country-level analysis shows 
that there is a surprising amount of homogeneity between countries in the estimated growth elasticities. Evidently, there is no pre-determined path to structural transformation and growth. But the empirical regularities are strong enough as to be able to make draw some broad conclusions. At odds with research by Wells and Thirlwall (2003), who test the applicability of Kaldor's growth laws for African countries and confirm that the manufacturing sector is the leading growth sector, our findings find only mixed evidence in support of Kaldor's first law in Latin America that manufacturing is the leading sector. In particular, we find strong evidence that segments of the service sector also: act as 'drivers' of economic growth, especially in the finance, commerce sectors and transport sub-sectors.

Of course, the association between growth of particular sectors and rising income tells us very little about the factors causing the rise in income itself. What the analysis does indicate is the pattern of resource allocation that normally accompanies a rise in income. As pointed out by Chenery (1960), growth is likely to be accelerated by anticipating desirable changes in resource use and retarded by institutional arrangements or government policies that inhibit such changes. This suggests that, despite the contemporary penchant for dismissing industrial policy out-of-hand, in the final resort governments may be 'doomed to choose' (Hausmann and Rodrik, 2006). ${ }^{17}$ As Hausmann and Rodrik put it,

"Industrial policy conceived as the provision of inputs that are specific to subsets of activities is not a choice; it is an imperative. The idea that the government can disengage from specific policies and just focus on providing broad-based support to all activities in a sector neutral way is an illusion based on the disregard for the specificity and complexity of the requisite publicly provided inputs or capabilities." (Hausmann and Rodrik, 2006: 24).

Nevertheless, our findings very much suggest that governments need to go beyond 'industrial policies' per se, and have a more proactive 'sectoral policy', which includes providing support to more dynamic sectors within the service sector as well as manufacturing. Our analysis also confirms the position of 'pessimists', regarding a reliance on traditional sectors (mining and agriculture) as a way of developing a dynamic, fast growing economy. In this sense, ideas about the existence of a 'resource curse' (Auty, 1993) do indeed seem to be well founded at least in the Latin American case.

Finally, our estimated elasticities of sectoral growth reflect the degree of articulation of an economy - that is, to Hirschman's well-known phrase, the strength of forward and backward linkages between sectors. For the more advanced economies of the region (e.g. Mexico, Argentina), the estimated elasticities are generally considerably higher than in the case of the poorer countries of the region, such as Honduras or Bolivia. But the results published here do suggest that, with the excep-

${ }^{17}$ The title of the Rodrik-Haussman paper is a play on words of the famous book of Milton Friedman, "Free to Choose". 
tion of the manufacturing sector, the changed policy environment since the end of the 1980s (the NEM) has led to a weakening of those linkages between sectors. In other words, Latin American economies have become increasingly disarticulated. Ongoing research into this question hopes to shed more light on both inter-country differences and the reasons for this apparent deterioration in the spillover effects between sectors.

\section{References}

[1] AGOSIN, M. (2006): "Trade and Growth: Why Asia Grows Faster than Latin America" in R. Ffrench-Davis and J.L. Machinea (eds), "Economic Growth with Equity Challenges for Latin America", Palgrave MacMillan, Basingstoke, pp. 201-219.

[2] ARELLANO, M. and S. BOND (1991): "Some Tests of Specification for Panel Data: Monte Carlo Evidence and an Application to Employment equations", Review of Economics and Statistics, 58, pp. 337-341.

[3] AUTY, RICHARD M. (1993): Sustaining Development in Mineral Economies: The Resource Curse Thesis. London: Routledge.

[4] BULMER-THOMAS, V. (2003): The Economic History of Latin America since Independence. New York, NY: Cambridge University Press.

[5] CAIRNCROSS, A. (1978): "What is De-Industrialisation?", in Frank Blackaby (ed), 'De-Industrialisation', Heinemann Education Books, London.

[6] CHENERY, H. B. (1960): "Patterns of Industrial Growth", The American Economic Review, Vol. 50, No. 4. (Sep., 1960), pp. 624-654.

[7] CIMOLI, M. and N. CORREA (2005): "Trade Openness and Technology Gaps in Latin America: A Low-Growth Trap”, in Jose Antonio Ocampo (Editor), 'Beyond Reforms - Structural Dynamics and Macroeconomic Vulnerability', Stanford University Press/World Bank.

[8] CUDDINGTON, J.T. and D. JERRETT (2008): “Super Cycles in Real Metals Prices?", IMF Staff Papers, Vol. 55, No. 4.

[9] DASGUPTA, S. and A. SINGH (2007): "Manufacturing, Services and Premature Deindustrialization in Developing Countries: A Kaldorian Analysis", in G. Mavrotas and A. Shorrocks (editors), Advancing Development, pp. 435-456, Palgrave Macmillan.

[10] DE SOTO, H. (1989): The Other Path: the Invisible Revolution in the Third Sector. New York, EU, Harper et Row.

[11] ECLAC (2005): Cuadernos Estadísticos, Series regionales y oficiales de cuentas nacionales, 1950-2002.

[12] ECLAC (2007): Economic Survey of Latin America and the Caribbean, 2006-2007, ECLAC, Santiago, Chile, www.eclac.cl

[13] HAUSMANN, R. and D. RODRIK (2006): "Doomed to Choose: Industrial Policy as Predicament", mimeo (first draft), September 2.

[14] HSIAO, C. (1986): 'Analysis of Panel Data', Cambridge University Press.

[15] HUMMELS, D. and P.J. KLENOW (2002): “The Variety and Quality of a Nation's Trade," NBER Working Papers 8712, National Bureau of Economic Research. 
[16] IM, K., PESARAN, M.H. and Y. SHIN (1997): Testing for Unit Roots in Heterogeneous Panels", Mimeo, Department of Applied Economics, University of Cambridge.

[17] IMBS, J. and R. WACZIARG (2003): "Stages of Diversification" American Economic Review, 93(1), pp. 63-86.

[18] IZQUIERDO A., R. ROMERO and E. TALVI (2008): "Booms and Busts in Latin America: The Role of External Factors", RES Working Papers 4569, Inter-American Development Bank, Research Department.

[19] JUDSON, R. and A. OWEN (1999): "Estimating dynamic panel data models: a guide for macroeconomists". Economics Letters 65, pp- 9-15.

[20] KALDOR, N. (1966): Causes of the Slow Rate of Growth of the United Kingdom, Cambridge: Cambridge University Press.

[21] KALDOR, N. (1975): "Economic growth and the Verdoorn Law - A comment on Mr. Rowthorn's article”, The Economic Journal, 85(340), pp. 891-96.

[22] KELLY, R. and G. MAVROTAS (2003): "Savings and Financial Sector Development: Panel Co-integration Evidence from Africa”, WIDER Discussion Paper No. 2003/12, World Institute for Development Economics Research of the United Nations University, Helsinki.

[23] KREGEL, J. (2007): "Nurkse and the Role of Finance in Development Economics," The Levy Institute of Bard College, Working Paper No. 520.

[24] KRUEGER, A. (2007): “The Financial Times Discusses Ha-Joon's New Book "Bad Samaritans", www.cepr.org

[25] LALL, S., M. ALBALADEJO and M. MESQUITO MOREIRA (2004): 'Latin American Industrial Competitiveness and the Challenge of Globalization', IDB INTAL-ITD Occasional Paper No. SITI- 05.

[26] LARSSON, R., J. LYHAGEN and M. LOTHGREN (2001): "Likelihood-based cointegration tests in heterogeneous panels," Econometrics Journal, Royal Economic Society, vol. 4(1), pages 41 .

[27] LEVIN A. and C.-F. LIN (1993): "Unit Root Tests in Panel Data: New Results," University of California at San Diego, Economics Working Paper Series 93-56, Department of Economics, UC San Diego.

[28] LEWIS, W. A. (1954): "Economic Development with Unlimited Supplies of Labour", The Manchester School, vol. 22, no. 2, pp. 139-191.

[29] MADDALA, G. S. and S. WU (1999): "A Comparative Study of Unit Root Tests with Panel Data and New Simple Test", Oxford Bulletin of Economics and Statistics, 61, pp. 631-652.

[30] MESQUITA MOREIRA, M. (2007): "Fear of China: Is there a future for manufacturing in Latin America?", World Development, Volume 35, Issue 3, March 2007, pp. 375-376.

[31] MOLD, A. and C. ROZO (2006): "Liberalization, growth and welfare: the 'maquilización' of the Mexican economy" in K. Sharma and O. Morrissey (eds.), 'Trade, Growth and Inequality in the Era of Globalization', Routledge, Abingdon, pp. 231-255.

[32] MULDER, N. (2002): "Economic Performance in the Americas: The Role of the Service Sector in Brazil, Mexico and the USA", Edward Elgar, Cheltenham.

[33] MURPHY, K., A. SHLEIFER and R. VISHNY (1989): "Industrialization and the big push" Journal of Political Economy, 97, pp. 1003-1026.

[34] OCAMPO, J.A. and M.A. PARRA (2003): "The Terms of Trade For Commodities In The Twentieth Century," The CEPAL Review, 79, pp. 7-35. 
[35] OECD (2009): Is Informal Normal? Towards More and Better Jobs in Developing Countries, OECD Development Centre Studies, Paris.

[36] PALMA, J.G. (2005): Four Sources of "De-Industrialization" and a New Concept of the "Dutch Disease" in José Antonio Ocampo, "Beyond Reforms - Stuctural Dynamics and Macroeconomic Vulnerability", Stanford University Press/World Bank.

[37] PREBISCH, R. (1950): “The Economic Development of Latin America and Its Principal Problems", United Nations, New York.

[38] RODRIK, D. (2007): “Industrial Development: Stylized Facts and Policies," in United Nations, Industrial Development for the $21^{\text {st }}$ Century, U.N., New York.

[39] ROSENSTEIN-RODAN, P. (1957): "Notes on the Theory of the Big Push" In Ellis and H. Wallick, Economic Development for Latin America, (Proceeding of the IEA Conference), St. Martins, New York, 1966.

[40] ROWTHORN, E. (1975): “What remains of Kaldor's laws?”, Economic Journal, 85, pp. $10-19$

[41] SINGH, A. and M. CERISOLA (2006): Sustaining Latin America's Resurgence: Some Historical Perspectives, IMF Working Paper WP/06/252.

[42] THIRLWALL, A. (2002): 'The Nature of Economic Growth - An Alternative Framework for Understanding the Performance of Nations", Edward Elgar, Cheltenham.

[43] THORP, R. (1998): Progress, Poverty and Exclusion - An Economic History of Latin America in the $20^{\text {th }}$ Century, Inter-American Development Bank, Washington.

[44] UNCTAD (2006): Least Developed Countries Report 2006 on Productive Capacities, UNCTAD, Geneva.

[45] UNIDO (2006): Industrial Development Report 2006.

[46] UNIDO (2009): Industrial Development Report - Breaking In and Moving Up: New Industrial Challenges for the Bottom Billion and the Middle-Income Countries.

[47] WELLS. H. and A.P. THIRLWALL (2003): "Testing Kaldor's Growth Laws across the Countries of Africa", African Development Review, 15(2), pp. 89-126.

[48] WILLIAMSON, J. (2003): "Our Agenda and the Washington Consensus" in Pedro-Pablo Kuczynski and John Williamson (eds), 'After the Washington Consensus - Restarting Growth and Reform in Latin America', Institute for International Economics, Washington.

[49] WOLFF, E. N. (2007): "Measures of Technical Change and Structural Change in Services in the USA: Was There a Resurgence of Productivity Growth in Services?" Metroeconomica, Vol. 58, No. 3, pp. 368-395, July 2007.

[50] WOOLDRIDGE, J. (2002): Econometric Analysis of Cross Section and Panel Data, MIT Press. 